\title{
Morphological Aspects of the Embryonic Development of the TMJ in Rats (Rattus norvegicus albinus) Treated With Fluoxetine
}

\author{
Aspectos Morfológicos del Desarrollo Embrionario de la ATM \\ en Ratas (Rattus norvegicus albinus) Tratadas con Fluoxetina
}

\begin{abstract}
"Ully Dias Nascimento Távora Cavalcanti; ${ }^{* *}$ Liriane Baratella Evêncio; ${ }^{* * * * * *}$ Joaquim Evêncio Neto; **** Raul Manhães de Castro; ${ }^{* * *}$ Aryana Soares Cardona; ${ }^{* * *}$ Marina Lins Maymone de Melo \& ${ }^{* * *}$ Rafael Claudino Lins
\end{abstract}

CAVALCANTI; U. D. N. T.; BARATELLA-EVÊNCIO, L. ; NETO, J. E.; CASTRO, R. M.; CARDONA, A. S.; MELO, M. L. M. \& LINS, R. C. Morphological aspects of the embryonic development of the TMJ in rats (Rattus norvegicus albinus) treated with fluoxetine. Int. J. Morphol., 27(3):899-903, 2009.

SUMMARY: The TMJ has been to the Dental community a key point in the search of knowledge, being it part of the temporomandibular joint complex and of the estomatognathic system which are in charge of the mastication, speech, swallowing, as well as participation in breathing and taste perception. For the majority of the women in serious state of depression, which do not respond psychotherapeutic treatment, pharmacological treatment it's applied. The antidepressants serotonin selective reuptake inhibitors (SSRIs) are the most recommended in these cases. The teratogenic effect of the SSRIs is considered controversial, studies done with women who used these drugs during the pregnancy showed that the respiratory and central nervous systems are the most affected, was also recorded a deficit of body growth and the decrease of the encephalon and skull measures. In the present study, our goal was to assess whether the administration of Fluoxetine during the pregnancy modified the embryology and morphology of the TMJ of rats. For that, 16 Wistar female rats from the Nutrition Department of the UFPE vivarium were selected; 8 for the control group, which received daily $0.9 \%$ of saline in subcutaneous dose of $10 \mathrm{ml} / \mathrm{g}$, with schedules previously established after daily weighing and 8 for the experimental one that were treated with fluoxetine hydrochloride with the dose of $10 \mathrm{mg} / \mathrm{Kg}$ in a volume $10 \mathrm{ml} / \mathrm{g}$ of weight, were injected subcutaneously with the same standards established for the control group. It was observed, with this dose that the embryological development of the TMJ, especially of the mandibular condyle, does not present any difference between the degree of maturation of the tissue that forms the TMJ, especially of the condyle between the treated and control groups.

KEY WORDS: TMJ; Mandibular condyle; Serotonin; Fluoxetine; Development.

\section{INTRODUCTION}

The Temporomandibular joint (TMJ) is a collection of anatomical structures that, with the participation of special groups of muscles, allows the jaw to perform various movements during mastication. It is a complex type of biaxial synovial articulation, formed by the articular discs, ligaments, synovial membrane (Figún \& Garino, 1994).

The embryologic development of the TMJ is marked by very peculiar process, because this articulation has, even in adulthood, the capability of adaptation and remodeling under external stimulation, therefore, several studies try to explain the histogenesis phenomenon, induction and histodifferenciation even before its functional activity in post-natal life. However, these phenomena are not sufficiently clarified and many details still need to be elucidated (Baume \& Holz, 1970; Keith, 1982; Fonzi, 1999; Krarup, 2005 ; Shen \& Darendelier, 2005).

\footnotetext{
Departament of Pathology - Pernambuco Federal University, Brazil.

* Departament of Histology and Embriology - Pernambuco Federal University, Brazil.

**** Pernambuco Federal University- UFPE, Brazil.

***** Departament of Nutrition - Pernambuco Federal University, Brazil.

****** Departament of Morphology and Animal Phisiology - UFRPE, Brazil.
} 
During embryogenesis, several neurotransmitters are involved in the process of histodifferenciation. The serotonin or 5-hydroxytryptamine (5-HT) is an indolamina product of hydroxylation and carboxylation of the amino acid LTryptophan, it is a neurotransmitter whose actions result from its interaction with specific molecular structures called serotoninergics receptors. The serotoninergic system stands out among the neurotransmitters systems involved in modulating the development and growth promoting regulation of epithelialmesenchymal interactions, stimulating the migration and cell differentiation during the formation of the neural tube and brachial arches, inducing the sprouting of different tissues (Moiseiwitsch \& Lauder, 1997; Magalhães et al., 2006).

The advancement of pharmacology promoted the emergence of highly selective substances that act specifically on certain neurotransmitters systems, serotonin selective reuptake inhibitors (SSRIs) drugs among them the fluoxetine are a group of drugs that presents few side effects, that are frequently prescribed for eating, emotional and sleeping disorders for patients of various ages, including during pregnancy and lactation (Ballone, 2005; Morrison, 2005; De Fátima et al., 2005).

Based on the ability of the SSRIs in causing malformations and changes in embryos reported by Magalhães et al.; Nomura \& Pinto e Silva (2007), we propose to examine embryological occurrence of possible changes in the development of TMJ, mainly in the condyle, of fetuses of rats, whose mothers were treated with fluoxetine.

\section{MATERIAL AND METHOD}

The study was conducted in the Histology Laboratory of the Department of Histology and Embryology in the Bioterium of the Department of Nutrition, the Laboratory of Histotecnicnology of the Pathology Department of the UFPE and in the Laboratory of Oral Pathology of the FOP/UPE. The experiment was approved by the animal experiment ethics committee of Pernambuco Federal Univesity (protocol 009330/ 2006-86). Albino Wistar rats were used of the colony of the Department of Nutrition of the UFPE. The animals received the standard diet of the Bioterium (LABINA - Purina do Brasil S/A) and water ad libitum. They were kept in rooms with temperatures of $23+/-2^{\circ} \mathrm{C}$ and clear and dark cycle of 12:12 (clear from 6:00 to 18:00 hours and dark from 18:00 to 6:00 hours).

To obtain newborns, were made adult animal mating in the proportion of one male to two females. As a criterion for inclusion was determined that the rats should weigh $250 \mathrm{~g}$ or have 150 days of birth, without prior mating or pregnancy.
The pregnancy was diagnosed through the observation of mucous buffer and vaginal smear, observation of the presence of sperm through the optical microscope and monitoring gain of body weight (weighing daily). Since this day was considered the 1 pc. 16 female Wistar rats were used, 8 for the control group (Group I) and 8 for the experimental (Group II) according to the calculation of the sample proposed by Yamaki et al. (2005). The animals were divided into 8 groups according to the age of the development of the TMJ to be studied (Yamaki et al.): group I fetuses with 13pc; group II, $14 \mathrm{pc}$; group III, $15 \mathrm{pc}$; group IV, $16 \mathrm{pc}$; group V, 17pc; group VI, $18 \mathrm{pc}$; group VII, 19pc and group VIII, with 20pc.

Treatment of the animals. Once diagnosed the pregnancy the rats were subjected to treatment established according with the study group to which they belonged in the first day of pregnancy. In the control group mothers received $0.9 \%$ of saline in subcutaneous dose of $10 \mathrm{ml} / \mathrm{g}$, at previously established times (between 12:00 and 13:00 hours).

In the experimental group the mothers were treated with fluoxetine hydrochloride in a dose of $10 \mathrm{mg} / \mathrm{Kg}$ in a volume of $10 \mathrm{ml} / \mathrm{g}$ of weight, injected subcutaneously at the same periods and timetables established for the control group.

The pregnant rats were anesthetized with xylazine $20 \mathrm{mg} / \mathrm{Kg}$ of the weight and ketamine, a $50 \mathrm{mg} / \mathrm{Kg}$ of weight and their fetuses removed by the peritoneal cavity. After collecting the material the rats were subjected to euthanasia by deepening the anesthetic field. The fetuses were immediately decapitated and their heads immersed in fixative solution of Bouin (Morton, 1950) followed by Light Microscopy procedures.

Histologic cuts were obtained with LEICA RT RM 2125 , adjusted to $5 \mu \mathrm{m}$-thick each and after all the histotecnical procedure stained with hematoxylin and eosin (HE), only then observed in biological trilocular photomicroscopy NIKON ECLIPSE 50i and their images captured with the program RV 480 optimedical.

\section{RESULTS AND DISCUSSION}

According to Yamaki et al. and Suzuki et al. (2005), in studies of rats with fetuses, the mesenchymal condensation occurs in the region of the TMJ from 14.5 days of intra-uterine life and the articular disc distinguished with 17.5pc For the $18.5 \mathrm{pc}$ the articular space was being formed and the endocondral ossification of the disc was observed around a cluster of hipertrofic chondrocytes. With $19.5 \mathrm{pc}$ there was a 

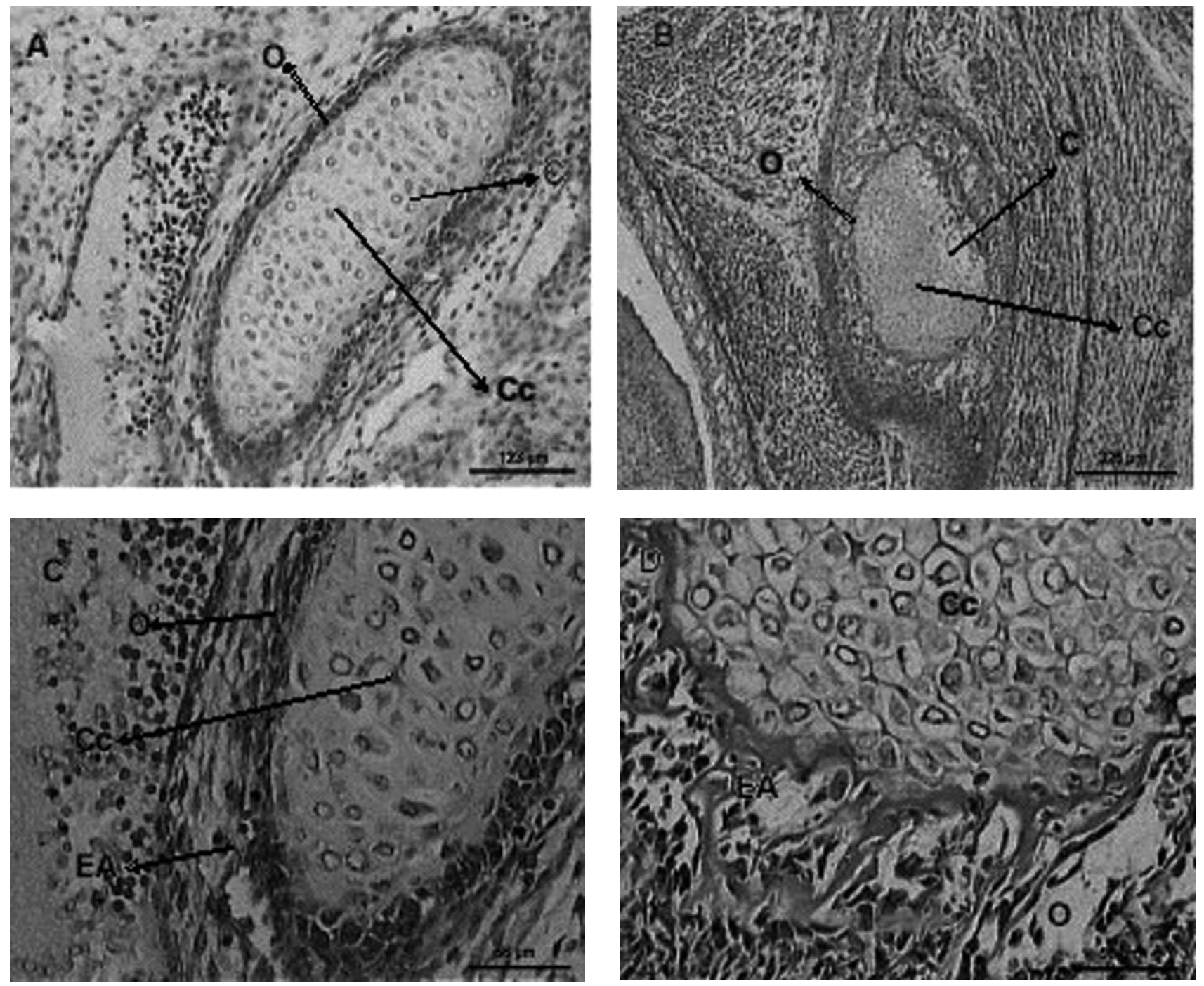

Fig. 1. Comparison of the sagittal cut between the control group (A and C) and treated group (B and D) with 18pc. Look ossification (O), condyle (C) central cartilage (Cc) and articular area (EA). 10X (A and B) and 20X (C and D) lens.

progression of the condyle, however, to $20.5 \mathrm{pc}$ the ossification of condyle had not been completed. Kawaga (1990), also reports that the differentiation and development of cartilaginous tissue in the posterior-upper portion of the jaw was observed from 13pc. This tissue grows upper, posterior and laterally continuously and maintain a constant articulation with the squamous portion of the temporal bone.

In our study, within the control group, we were able to confirm the data obtained by Yamaki et al. and Kawaga when we could not distinguish clearly the TMJ of the 13pc to $17 \mathrm{pc}$ fetuses, only a condensation mesenchymal without defined contours. We could observe from 18pc the presence of a spherical condyle, with a central cartilage circumvented by a strip of ossification. In the $19 \mathrm{pc}$ we observed the same components in a more advanced stage. In the $20 \mathrm{pc}$ was observed the ossification process more advanced but not complete, showing at this stage the articular cavity completely formed, the cartilaginous matrix with a lot of intercellular substance suggesting mature tissue, the chondroblasts of the periphery of the condyle was flattened shape and appearing in large quantity suggesting cellular proliferation and secretion also agreeing with the observations of Yamaki et al.

In our study, when comparing the group treated with the control group we found that occurs similarity of the embryological morphological development of the TMJ in both groups.

Given the obtained results, with a dose of fluoxetine of $10 \mathrm{mg} / \mathrm{Kg}$ in a volume weighting $10 \mu / \mathrm{g}$, was possible to conclude that there is no difference in the embryology and morphology of the TMJ in the studied groups. 

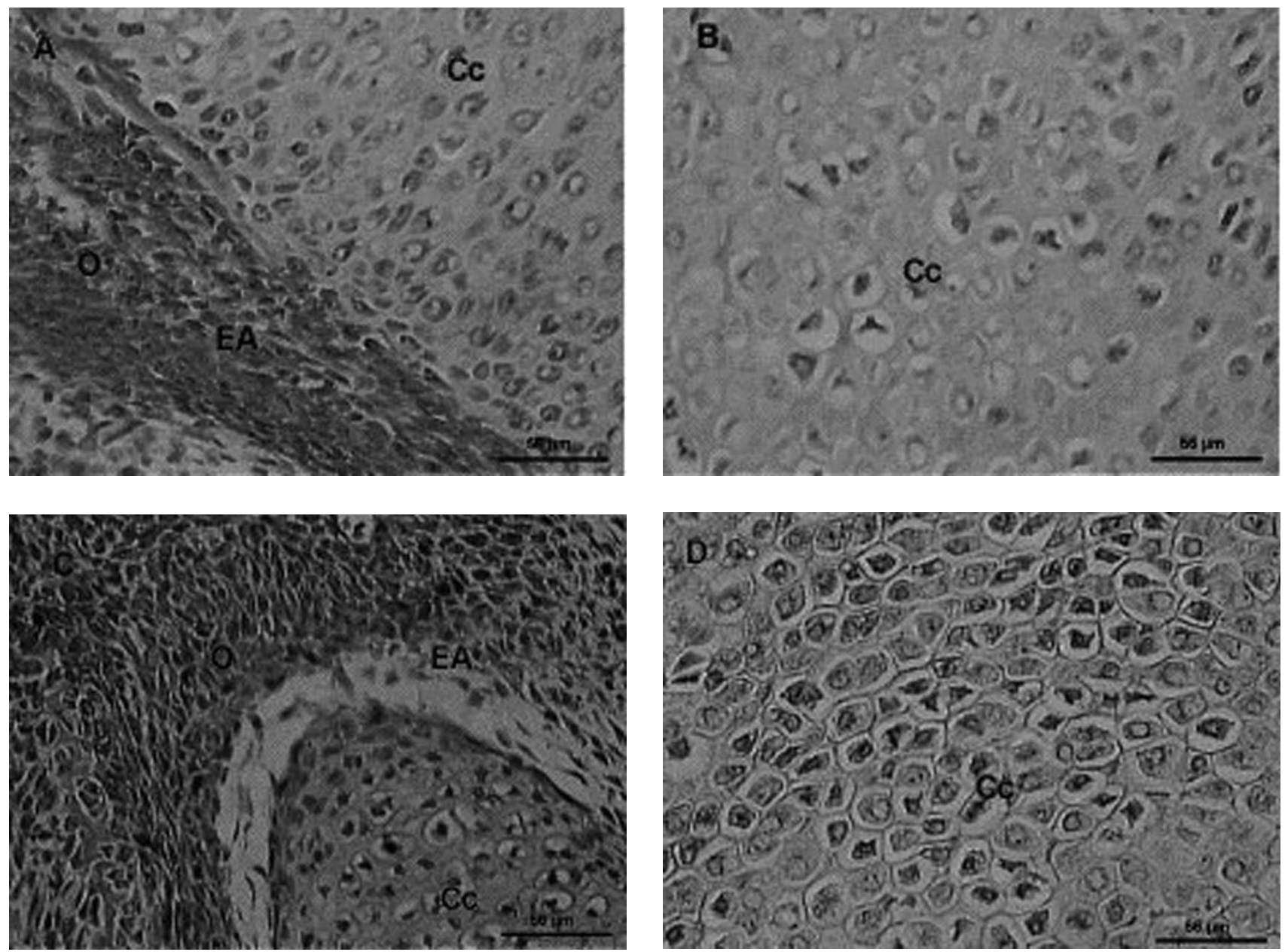

Fig. 2. Comparison of the sagittal cut between the control group (A and B) and treated group (C and D) with 20pc. Look Ossification (O), Condyle (C), Central cartilage $(\mathrm{Cc})$ and aticular area (EA). 20X lens.

CAVALCANTI; U. D. N. T.; BARATELLA-EVÊNCIO, L. ; NETO, J. E.; CASTRO, R. M.; CARDONA, A. S.; MELO, M. L. M. \& LINS, R. C. Aspectos morfológicos del desarrollo embrionario de la ATM en ratas (Rattus norvegicus albinus) tratadas con fluoxetina. Int. J. Morphol., 27(3):899-903, 2009.

RESUMEN: La ATM ha sido para la comunidad odontológica un punto clave en la búsqueda del conocimiento, dado que forma parte del complejo articular temporomandibular y del sistema estomatognático, los cuales se encargan de la masticación, fonación y deglución, así como la participación en la respiración y de la percepción gustativa. Para la mayoría de las mujeres con cuadros graves de depresión, que no responden al tratamiento psicoterapéutico, el tratamiento farmacológico es aplicado. Los antidepresivos del grupo de los Inhibidores Selectivos de Recaptación de Serotonina (ISRSs) son los más comúnmente recomendados en estos casos. El efecto teratogénico de los ISRSs es considerado controversial. Estudios realizados en mujeres que utilizaron estas drogas durante la gestación mostraron que los sistemas respiratorios y nervioso central son los más afectados, también fue constatado un déficit de crecimiento corporal, encefálico y disminución de las medidas craneales. En el presente estudio, nuestro objetivo fue evaluar si la administración de fluoxetina durante la gestación modifica la embriología y la morfología de la ATM de ratas de laboratorio. Para este fin, 16 ratas Wistar del bioterio de nutrición de la UFPE fueron seleccionadas: 8 para el grupo de control, las cuales recibieron diariamente solución fisiológica a $0,9 \%$ en aplicaciones subcutáneas en la dosis de $10 \mathrm{ml} / \mathrm{g}$, en horarios previamente establecidos después de pesaje diario y 8 para el experimental, las que fueron tratadas con clorhidrato de fluoxetina en la dosis de $10 \mathrm{mg} / \mathrm{kg}$, en un volumen de $10 \mathrm{ml} / \mathrm{g}$, inyectados por vía subcutánea en los mismos estándares establecidos para el grupo de control. Se observó, que con esta dosis el desarrollo embriológico de la ATM, especialmente del cóndilo mandibular, no presentó ninguna diferencia entre el grado de maduración de los tejidos que forman la ATM, especialmente del cóndilo, entre los grupos tratado y grupo control.

PALABRAS CLAVE: ATM; Cóndilo mandibular; Serotonina; Fluoxetina; Desarrollo. 
CAVAlCANTI; U. D. N. T.; BARATElla-EVÊNCIO, L. ; NETO, J. E.; CASTRO, R. M.; CARDONA, A. S.; MELO, M. L. M. \& LINS, R. C. Morphological aspects of the embryonic development of the TMJ in rats (Rattus norvegicus albinus) treated with fluoxetine. Int. J. Morphol., 27(3):899-903, 2009.

\section{REFERENCES}

Ballone, G. J. Gravidez e Medicamentos - In. PsiqWeb. Disponível em: http://www.psiqweb.med.br., 2005.

Baume, L. J. \& Holz, J. Ontogenesis of the human temporomandibular joint. 2. Development of temporal components. J. Den. Res., 49(4):864-75, 1970.

De Fátima, A.; Lapis, A. A. M. \& Pilli, R. A. Concise total synthesis of (R)-Fluoxetine, a potent and selective serotonin reuptake inhibitor. J. Braz. Chem. Soc., 16(3A):495-9, 2005.

Figún, M. E. \& Garino, R. R. Anatomia Odontológica Funcional e Aplicada. $3^{\circ}$ Ed. São Paulo, Panamericana, 1994.

Fonzi, L. Review of the morphogenesis of the mandibule and temporomandibular joint. Bull. Group Int. Rech. Sci. Stomatol. Odontol., 41(1):48-52, 1999

Kagawa, M. A serial study on the development of the temporomandibular joint in fetal mouse -in particular on the fibrous component in condylar cartilage. Nippon Kyosei Shika Gakkai Zasshi, 49(3):187-98, 1990.

Krarup, S.; Darvann, T. A.; Larsen, P.; Marsh, J. L. \& Kreiborg, S. Tree-Dimensional analysis of mandibular growth and tooth eruption. J. Anat., 207(5):669-82, 2005.

Keith, D. A. Development of the human temporomandibular joint. Br. J. Oral Surg., 20(3):217-24, 1982.

Magalhães, C. P.; Lima, L. O.; Silva, M. C.; Marinho, S. M.; Nascimento, E.; Silva C. M.; Souza, S. L. \& Manhaes De Castro, R. Efeitos do tratamento neonatal com inibidor seletivo de recaptura da 5 -TH sobre o desenvolvimento anatômico crânio-encefálico. Arq. Neuropsiquiatr., 64(4):990-3, 2006.

Moiseiwitsch, J. R. \& Lauder, J. M. Regulation of gene expression in cultured embryonic mouse mandibular mesenchyme by serotonin antagonists. Anat. Embryol., 195(1):71-8, 1997.

Morton, J. E. Collecting and preserving zoological specimens. Tuatara, 3(3):104-14, 1950.

Morrison, J. L.; Riggs, K. W. \& Rurak, D. W. Fluoxetine during pregnancy: impact on fetal development. Reprod. Fertil. Dev., 17(6):641-50, 2005.

Nomura, M. L. \& Pinto e Silva, J. L. C. Riscos e benefícios do uso dos inibidores seletivos da recaptação de serotonina para depressão durante a gravidez e lactação. Rev. Bras. Ginecol. Obstet., 29(7):331-6, 2007.

Shen, G. \& Darendeliler, A. The adatative remodeling of condylar cartilage-A transition from chondrogenesis to osteogenesis. J. Dent. Res., 84(8):691-9, 2005.

Suzuki, A.; Nozawa-Inoue, K.; Ikeda, N.; Amizuka, N.; Ono, K.; Takagi, R. \& Maeda, T. Development of the articular cavity in the rat temporomandibular joint whith special reference to the behavior of endothelial cells and macrophages. Anat. Rec. A. Discov. Mol. Cell Evol. Biol., 286(2):908-16, 2005.

Yamaki, Y.; Tsuchikawa, K.; Nagasawa, T. \& Hiroyasu, K. Embryological study of the development of the rat temporomandibular joint: highlighting the development of the glenoid fossa. Odontology, 93(1):30-4, 2005.

\author{
Correspondence to: \\ Disciplina de Histologia e Embriologia Oral \\ Universidade Federal de Pernambuco \\ Av. Prof. Moraes Rego, 1235 \\ Cidade Universitária \\ CEP: 50670-901, \\ Recife - PE \\ BRASIL \\ Fone PABX: (81) 2126.8000 \\ Fax: (81) 2126.8029 \\ Email: ullydias@yahoo.com.br
}

Received: 28-10-2008

Accepted: 22-05-2009 
